\title{
Tobacco Smoking History
}

National Cancer Institute

\section{Source}

National Cancer Institute. Tobacco Smoking History. NCI Thesaurus. Code C29719.

A record of an individual's background in regard to smoking tobacco. This would include such factors as start date, end date (if applicable), number of cig arette smoked, attempts to quit, and others. 